\title{
Entrepreneurial opportunity as the potential to create value
}

\author{
Peter Lewin
}

Published online: 10 November 2013

(C) Springer Science+Business Media New York 2013

\begin{abstract}
Unpacking the concept of entrepreneurial-opportunity to include three categories of essential ingredients, provides a fruitful framework for applying Israel Kirzner's approach to entrepreneurship — bridging the entrepreneur as someone alert to opportunities to create value, to real world situations requiring the entrepreneur's evaluation of resource-inputs and prospective outputs, and his perception of what actions are necessary and need to be coordinated, in an environment of sufficient mutual understandings. To fully understand how the entrepreneur makes superior evaluations, one must address all of these three categories.
\end{abstract}

Keywords Entrepreneur - Opportunity · Alertness · Incentives · Business-management

\section{Introduction-The argument in brief}

The essence of Israel Kirzner's approach to entrepreneurship is alertness to entrepreneurial opportunities. Entrepreneurial opportunities are essentially arbitrage opportunities that exist because of the undervaluation of resources in the market. The entrepreneur "sees" a way to combine these resources in order to produce a product whose market value will exceed the market value of this combination and hence earn a profit. In this way, entrepreneurship provides a systemic coordinating function in facilitating the deployment of resources to their most highly-valued uses. Kirzner's life-long exploration of this theme has provoked much appreciative and critical discussion within the economics profession and, especially, within Austrian economics.

Recently, interest in his work has emerged and rapidly expanded in the field of management studies, and, particularly, in the growing sub-field of entrepreneurship studies. It is hard to find an article in this field which does not address the question of entrepreneurial opportunities and how they are perceived and exploited. A veritable industry of research into the nature, causes and effects of entrepreneurial opportunities has arisen in a very short time (some references are provided below).

P. Lewin $(\square)$

Naveen Jindal School of Management, University of Texas at Dallas,

800 W Campbell Road, Richardson, TX 75080, USA

e-mail: plewin@utdallas.edu 
It is clear, however, that the concept "entrepreneurship" as conceived by Kirzner and as researched in this field of entrepreneurial studies are very different. There is a clear disconnect that is the result of different projects. Kirzner's work is motivated by interest in the functioning of market systems as a whole and the role of entrepreneurship therein. Management scholars, by contrast, are interested in what accounts for entrepreneurial success and failure, that is, in the details of the entrepreneurial mind and the nature of entrepreneurial abilities. This literature thus involves investigations from cognitive psychology, sociology, network theory, strategic management, political theory, organizational theory as well as economics. The imagination of these researchers has been fired by Kirzner's work which provided an unintended opportunity for entrepreneurial research to branch out into unexplored territory, the territory of opportunity-discovery in all of its manifold aspects.

The differences between these two visions of entrepreneurship is related to wellknown issues with Kirzner's theory. For Kirzner entrepreneurship is a function and is not coextensive with any person or his actions. For Kirzner, the entrepreneurial act is constituted by, and only by, the momentary perception of the arbitrage opportunity; it is a revelation, an epiphany. The entrepreneur "sees" the value-differentials that constitute a profit opportunity. The execution of the opportunity is another (more mundane) matter. Once the opportunity is revealed it remains for the manager (who might be the same person) to act out its (obvious?) implications. Critics have pointed to logical problems with this (discussed below). The most significant perhaps is the connection between opportunity discovery and incentives. Kirzner posits that alert entrepreneurs discover opportunities and that alertness responds to incentives to be alert. Kirzner wants to draw policy conclusions. So he needs to tie entrepreneurial opportunity discovery to policies that produce the right incentives. The inability to convincingly do this has been a problem for the theory.

For the management research that his work has spawned however, the focus is different. These researchers are interested in explaining entrepreneurship for its own sake, and in much more detail. Their research looks at real world entrepreneurs. In the examination of opportunities they have moved away from, beyond, Kirzner's opportunity as momentary revelation.

My primary purpose in this paper is to subject the Kirznerian entrepreneurial opportunity to a more thorough examination and to suggest a shortcoming that has not yet surfaced. In short, I maintain that the kind of bare-bones perception of an arbitrage opportunity won't fly. It cannot square with what we know about how human's think and how they experience time. When we unpack the various essential (undeniable) components of real entrepreneurial opportunities (of which there are three categories) we find an inescapable link to the work of the management scholars. When opportunities are seen as real-world contextual phenomena in which a perceived opportunity to create value contingent upon certain concrete actions and understandings, Kirzner's arbitrage approach emerges more defensible and useful. The list of works analyzing the content and meaning of the concept of entrepreneurial opportunity is large (for a review see Short et al. 2009). The one offered here is suggested for its clarity, simplicity, ease of applicability and originality.

The next section briefly summarizes the main elements of Kirzner's theory of entrepreneurship. The section following rehearses briefly the criticisms that have been leveled against it. I then turn to the core contribution of this paper-an examination of 
the "insides" of any entrepreneurial opportunity. We find that all entrepreneurial opportunities have three categories of ingredients-evaluations, actions and understandings and that when this is clearly spelled out, a reexamination of the criticisms (undertaken in the next section following) yields a different perspective.

Entrepreneurial opportunities refer in this paper to market opportunities. Entrepreneurs exist in other settings as well. The penultimate section briefly discusses entrepreneurship in highly regulated environments and the role of political entrepreneurs in transforming such environments. We end with some concluding remarks.

\section{Kirzner's entrepreneur}

According to Kirzner, an entrepreneur is someone who notices, by being alert, hitherto unperceived opportunities for gain. One who is alert to such opportunities is thus likely to be a better entrepreneur than one who is not. An entrepreneurial opportunity exits whenever inputs can be bought (or rented) and used to produce an output of greater market value (due account being taken of interest as a cost of production). ${ }^{1}$ Exploiting opportunities will lead (if they are real and not just imagined) to entrepreneurial profit. Profits are thus the reward for correctly perceiving and exploiting available opportunities.

Kirzner has developed some interesting implications of this approach. First, the entrepreneurial function must be sharply distinguished from that of the owner, producer or manager. Though in practice successful entrepreneurs are often owners, managers and producers, they are coincidentally combining these two functions in one person. In principle they could be, and often are, found in separate people. The entrepreneurial function consists in providing the "vision," the insight as to what can be done. Once the opportunity has been revealed the entrepreneurial work is done. Implementing the vision may involve calculation, sequencing, monitoring, financing and so on. But insofar as the opportunity is already perceived the entrepreneurial aspect is over.

Second, entrepreneurship is thus "costless." Something which is "costly" can be bought and allocated to consumption or production. Its purchase requires a decision, a choice. A sacrifice must be made. This is what economists usually understand by the term "cost." The cost of something is what you consciously have to give up to get it. And, an opportunity noticed by an alert entrepreneur uses no resources in the noticing of it. To be alert implies no opportunity cost. ${ }^{2}$

\footnotetext{
${ }^{1}$ As already mentioned the essence of Kirzner's theory of entrepreneurship is arbitrage. The observation of a discrepancy in the price of a good in two different places suggests the opportunity to buy at the lower and sell at the higher price. The same is true of a perceived "undervaluation" of any good-presenting the opportunity to buy it now and sell it profitably latter (assuming it can be carried through time, or that an option to buy it later at today's price can be purchased). Production (including distribution) is just a special, more complex, instance of normal arbitrage.

2 "In using any quantity of a scarce resource ... the decision-maker is always viewed as choosing between alternative goals to which the scarce resource may be applied. The goal forgone is the cost of using the resource for its present purpose. In the use of entrepreneurial alertness, however, a decision-maker never considers whether to apply some given potential alertness to the discovery of opportunity A or opportunity B ... [O]pportunities ... are either perceived or not perceived; alertness is not something about which a decision can be made not to deploy it .... To recognize that opportunity A exists need not preclude simultaneously recognizing that opportunity B exists.” (Kirzner 1980, p. 24).
} 
This also implies that an entrepreneurial opportunity is not something for which one can search. In makes no sense to talk about searching for an opportunity about which one does not know. The value of an entrepreneurial opportunity obviously cannot be known before it is perceived. One cannot, therefore, efficiently and rationally allocate effort toward its perception. Search is thus not something to associate with an entrepreneurial opportunity. ${ }^{3}$

Third, in spite of this, Kirzner maintains that entrepreneurial alertness, and thus, the discovery of opportunities depends on the incentives that operate in different types of social systems. Only in a market system, he argues, is it in the interest of the entrepreneur to notice a profit opportunity and "human beings tend to notice that which it is in their interest to notice" (Kirzner 1980, p. 28.) In the absence of private property or of some mechanism for evaluating productive resources the entrepreneurial process could not work. This process depends on freely changeable prices to reveal opportunities and on the ability to exploit those opportunities. In a non-market system (or even a highly regulated one) planners and bureaucrats would have to be alert to these opportunities. They would be noticed only with extreme difficulty. Even if they were noticed planners and regulators have no direct incentive to exploit them or bring them to the notice of those who do. Thus, although entrepreneurship is not a resource in the usual sense, it is a function that is crucial to the market process and one that can exist fully only within such a system (Kirzner 1985, chapter 6).

Fourth, entrepreneurship depends on error. An opportunity for profit exists only if it has not already been noticed. In a sense, it reflects a "hole in the market." The market values of products and resources do not reflect the value of the unnoticed opportunity. If it suddenly became widely known that certain resources could be more profitably used than they have been until now, their market value would rise immediately. Similarly, if the price of a commodity differed in two locations by more than the transportation cost, widespread knowledge of this would immediately result in the disappearance of the price discrepancy (net of transportation costs). In both cases sellers and buyers would immediately revalue the resources and commodities to reflect the opportunities for production and resale. An unexploited, unnoticed opportunity thus, by definition, reflects a market error (Kirzner 1973, 1979).

\section{Kirzner's theory of entrepreneurship critically considered}

Kirzner's theory of entrepreneurship has attracted many criticisms that are by now quite well-known. A brief account is provided here (for fuller summaries see Lewin 2002; Foss and Klein 2012, chapter 3; McCaffrey 2013).

\footnotetext{
${ }^{3}$ This is closely related to the well-known critique of neoclassical search theory. Marginal maximization calculus cannot coherently be applied to the allocation of effort in search of benefits the value of which will be revealed by the results of that search. Such an application would presume to know the results of the search, thus rendering it unnecessary. And this is an instance of a set of general problems in which the value of today's efforts will depend upon events yet to be revealed, and the knowledge that they bring. In (Karl) Popper's terms, we cannot coherently imagine having knowledge of future knowledge. Yet effort is allocated toward activities whose payoff cannot be known, as in the case of R\&D. Some weighing of the value of efforts in this regard must be taking place. Kirzner's characterization of entrepreneurship as costless thus bears further examination. This is provided in the next section.
} 
The perception of entrepreneurship as something that is costless, spontaneous and crucial to the market system, raises some interesting difficulties. In particular, it provokes the questions: How does entrepreneurship arise? Where does it come from? What are the antecedent conditions for individual entrepreneurship? It is basic to Kirzner's notion of entrepreneurship that it is not produced in the usual sense. Yet Kirzner wants to maintain that certain conditions facilitate its emergence.

One possible response is the assertion that entrepreneurship is intrinsic to human nature - not to the same extent in all human beings, but, nevertheless, a basic trait. The tendency to "truck and barter" referred to by Adam Smith, can be seen as a reflection of the basic (instinctual?) desire and ability to make a profit. Entrepreneurship then is not "produced," it exists always, perhaps in latent form, waiting to be tapped by the right set of conditions.

There is some considerable appeal in this approach. Casual observations of different social conditions across time and space suggests that a resilient entrepreneurial spirit resides eternal in the human breast. Indeed, it appears that it is not something that is confined to people of a certain culture, social background, education or any other acquired characteristic. People moving between societies (for example from nonmarket to market societies) often turn out to be outstanding entrepreneurs.

Thus while clearly "pure" entrepreneurship cannot be produced, in the usual sense of the term, and cannot be predicted, is entrepreneurial ability not predictably related to certain characteristics that are definitely produced? For example, is the ability to read and write not necessary to perceive certain types of opportunities? Or the ability to calculate? These abilities are produced. They are the products of a conscious human capital investment decision. It seems clear that, whether or not we characterize entrepreneurship as a scarce resource, it can be facilitated and nurtured by certain conditions. While individual opportunities obviously cannot be predicted, the emergence of opportunities (as a category) surely can be said to be more likely under some circumstances than others.

Indeed, Kirzner was concerned exclusively with the systemic implications of entrepreneurship. It is the entrepreneur who provides the answer to the question: how do equilibrium prices ever get established in a dynamic world? Without the entrepreneur, the market economy could not function and anything that impedes the entrepreneurial function, will encumber the smooth functioning of the market (Kirzner 1980). So Kirzner's research is directed toward providing an understanding of the market process in general and economic policies appropriate to the fostering of entrepreneurship.

As mentioned, the management literature is interested in Kirzner's work for different reasons. It is his concept of "opportunity discovery" that has recently become the central focus of research into the nature and workings of entrepreneurship in real world markets, most notably by Scott Shane and his collaborators (Shane 2000, 2004; Shane and Venkataramon 2000; Eckhardt and Shane 2003). Drawing from Kirzner's basic idea, Shane enquires into the nature of entrepreneurial opportunities and the people who discover and exploit them. And a large literature has grown up around these themes. Shane's entrepreneur (and the entrepreneur depicted in the large literature that is has spawned) is, however, not Kirzner's entrepreneur. The latter is a disembodied function whose general characteristics lie beyond the realm of empirical research. Kirzner's contribution to the management 
literature, though substantial if one notes the large number of studies - empirical and theoretical-leveraging the concept of "opportunity," was unintended (Kirzner 2009). Shane, et al. are interested in the real-world antecedents of entrepreneurship, in the characteristics of real-world entrepreneurs, in the real-world incentives that stimulate entrepreneurial activity, and son on. Much of the related management literature is thus implicitly or explicitly critical of Kirzner's theory of the entrepreneur as a disembodied, incentive-independent, costless function, even while using it appreciatively to focus on the role of entrepreneurial profit opportunities (for a recent summary see McCaffrey 2013).

Some new research in the field of entrepreneurship, also provoked by Kirzner's work contrasts his approach with that of other historical approaches, for example, Joseph Schumpeter's approach to entrepreneurship, which emphasized disequilibrium and creative destruction (Schumpeter 1911, 1942); or Ludwig von Mises's approach to the entrepreneur emphasizing the role the entrepreneur plays in appraising the value of resources in a world in which the future is unknown (Mises 1998 [1949]; or, most notably, Frank Knight's work which famously drew attention to the role of uncerntainty (where the set of possible outcomes was unknown and unknowable) as distinct from risk (where the set of possible outcomes was known and probabilities could be attached to them) (Knight 1921). Knight proposed that the entrepreneur supplies judgement in order to make decisions in an uncertain world, and judgement has recently been emphasized as a crucial aspect of entrepreneurship in a number of recent contributions (for example, Klein 2008; Foss and Klein 2008, 2010,2012 ). In this approach, whether opportunities are created or discovered is seen to be less important than an understanding of the role of the entrepreneur in exploiting them. It is this approach that I wish to build on in the next section.

\section{The essential ingredients of entrepreneurial opportunity}

Much of the discussion surrounding the nature of entrepreneurial opportunities is immersed in the thicket of language - to discover, to create, to be alert, what exactly do they this mean and how closely do they describe the reality of entrepreneurship? I suggest here a clarifying conceptual framework, a reformulation in which these concepts will appear more clearly and less prone to paradox and conflict. What is missing from the current discussion is a focus on two key aspects of entrepreneurship and entrepreneurial opportunities - the importance of the real time context of entrepreneurial action and its embeddedness in a real-world context and, relatedly, the subjective nature of opportunities. ${ }^{4}$

\footnotetext{
${ }^{4}$ Davidsson advocates for dropping the term "opportunity" altogether: "The term "opportunity" refers to something not yet realized. The increased use of this term in entrepreneurship research therefore signals the sound development that the field is really turning towards a focus on emergence, rather than starting from existing firms and established business founders. However, there is a huge linguistic problem with adopting "opportunity" as a central concept in entrepreneurship research. By almost any definition, an opportunity is something known to be favorable. ... the use of the term "opportunity" for an unproven venture idea is fundamentally opposed to acknowledging uncertainty as an inescapable aspect of the environment .... (Davidsson 2004: 506-521). For this reason we stress the "potential" aspects of the entrepreneurial opportunity.
} 
Kirzner is surely correct that exploiting an entrepreneurial opportunity involves combining (organizing) productive resources in a novel way to produce something whose value exceeds the total cost of production - namely, the cost of paying for the labor-services needed (wages), plus the cost of paying for the services of the diverse types of physical capital used (machines, raw materials, facilities, transportation, storage, etc. $)^{5}$ plus any interest cost. Any excess over this is profit. As Mises has very clearly explained:

What makes profit emerge is the fact that the entrepreneur who judges the future prices of the products more correctly than other people do buys some or all of the factors of production at prices which, seen from the point of view of the future state of the market, are too low. Thus the total costs of production-including the interest on the capital invested - lag behind the prices which the entrepreneur receives for the product. This difference is entrepreneurial profit. (Mises 1980:109 [1951], italics added).

Opportunities are forward-looking, they involve future prospects. Time must pass before we really know whether this is a bona fide opportunity yielding profit. Also, crucially, the earning of profit is contingent upon certain things happening, certain actions need to be taken; the passage of time alone is insufficient. An opportunity is a prospect that is based on the expectations of the entrepreneur (or entrepreneurial team) concerning many contingent ingredients, including the current and future values of the services of the factors of production and the future values of the output to be produced and sold, which, in turn, depends on the future valuations of consumers. It is well-known that the values (prices) of the services of the factors of production (the inputs) are characterized by uncertainty, by the need to estimate and anticipate certain key aspects; for example, when resources are owned, the user/accountant must estimate their costs until the "true" cost of using them is revealed by the need to replace, repair or maintain them sometime in the future. Similarly, and even moreso, the value of the outputs is an uncertain matter (Lewin 1998). In addition, the earning of profit will be contingent upon actions of suppliers, competitors, bankers, etc. and on their sharing an understanding of what kinds of actions are permissible and expected of them.

We can formalize this by saying that each entrepreneurial opportunity contains three kinds of related ingredients that will determine its value, namely, evaluation, actions and understandings (Table 1).

The success of any opportunity for profit will depend, most basically, on a correct understanding of the technology_not of the technical details, but of the economic implications of the physical processes and resources involved. Secondly, the actions of the various players in the supply-chain need to be coordinated to ensure appropriate flows of material and services at the right time. There is a time structure, a sequencing logic, to the supply process. This coordination will be crucially

\footnotetext{
${ }^{5}$ The cost of using physical capital is dimensionally the same as the cost of using labor. Labor is not purchased, it is rented, and the rental cost per time-period is the wage-rate. Physical capital can be purchased and owned or it can be rented. The cost of using it is its rental-rate, the cost of purchasing its services. If it is owned then the cost of using it is the implicit cost of renting it "from oneself." Much confusion concerning the concept of rent as a surplus could be avoided by using this conceptual framework (Lewin and Phelan 2001)
} 
Table 1 Ingredients of Opportunity

\begin{tabular}{llc}
\hline Evaluation & Actions & Understandings \\
\hline $\begin{array}{l}\text { Current and expected } \\
\text { future values of } \\
\text { inputs and outputs. }\end{array}$ & $\begin{array}{c}\text { Coordinated actions of suppliers, } \\
\text { workers, bankers, ..., expected } \\
\text { actions of competitors. }\end{array}$ & $\begin{array}{c}\text { Laws, customs, industry standards and } \\
\text { practices, tacit agreements, ... . Correct } \\
\text { understanding of the implications of } \\
\text { the production process. }\end{array}$ \\
\hline
\end{tabular}

dependent on a high degree of shared understandings, many tacit in nature (part of the "culture of the context"). In part, this coordination will be aided by the macro and micro institutional framework - the rule of law, the industry standards and practices; in part by the tacit, unconscious ways of doing things. In addition, the actions of competitors must be correctly anticipated so as not to have them disrupt the profit opportunity.

It follows from this that knowledge about opportunities must be idiosyncratic. If too many people know about a (potential) opportunity, it may not be exploited. There is a strategic problem when everyone perceives an opportunity whose value depends on not too many people trying to exploit it. G. B. Richardson (1960) has insightfully explained this:

It may seem paradoxical to regard ignorance, in its role as a restraint on investment, as actually furthering, in certain circumstances, a successful [exploitation of opportunities for profit]. And yet it is clear that an entrepreneur may undertake a certain project chiefly on the grounds that only he, and possibly a very few other producers, are aware of the impending increase in demand. Ignorance, by checking the response of some, may be a necessary condition for any response by others; an unequal distribution of knowledge of final demand, therefore, may actually promote successful adjustment. A general profit opportunity, which is both known to everyone, and equally capable of being exploited by everyone is, in an important sense, a profit opportunity for no one in particular; it will create the incentive to invest only provided some people are less able to discern it, or to respond to it, than others. (Richardson 1960, p 57-58). ${ }^{6}$

Richardson refers to these conditions of ignorance and inertia as "helpful imperfections," the real world, a world in time in which entrepreneurial expectations and abilities are heterogeneous in nature. Entrepreneurial producers may indeed possess, and need to possess, a kind of "temporary monopoly of information about a general profit opportunity. ... Profits may be earned,... both by foresight and by innovation."

\footnotetext{
${ }^{6}$ Also: "[O]pportunity finds its meaning in the context of human action and human action occurs within the flux of time, making it inherently uncertain (Mises 1998 [1949]). Thus it seems that one cannot have opportunity without uncertainty but because the human condition is characterized by the passage of time, there will always be uncertainty and therefore, some form of opportunity. ... individuals appear to experience uncertainty differently as a function of knowledge, motivation, ability, geography, etc. enabling some but not others to act." (McMullen et al. 2007, p 279).

7 Alvarez and Barney refer to "competitive imperfections" (2007, p 13).
} 
(Richardson 1960: 57). No producer enters a market that is a "clean slate"- there is history. An opportunity obvious to one person may be invisible to another because he sees the world through different lenses framed by different experiences and presumptions. This is a necessary part of the market process as an implicit experimental process that pits one perceived opportunity against another.

We turn to a reconsideration of the discussion of entrepreneurial opportunity in the literature.

\section{Opportunity critically reconsidered}

\subsection{Antecedents and incentives 8}

Kirzner's assertion that entrepreneurial alertness is stimulated by the right incentives, because "human beings tend to notice that which it is in their interest to notice"(Kirzner 1980, p. 28.) has been widely analyzed and criticized (McCaffrey 2013, provides a comprehensive account). The assertion is not self-evident and is arguably not universally true. One may think of situations in which it seems as if individuals have failed to notice what is in their self-interest. At the very least, this assertion contains sufficient ambiguity to be highly questionable. But, more importantly, as already noted, the notion that entrepreneurs are passively alert to opportunities - using no resources to discover them-seems to be logically inconsistent/incoherent. How can incentives stimulate something that is not actively chosen or sought-after?

One way to respond, as already noted, is to treat the notion entrepreneurial opportunities as a category of events and argue that, because certain background circumstances produce more opportunities than others, more of them will be discovered in those circumstances. So, in a way, entrepreneurial opportunities are "produced" by policies that conduce to the right kind of environment. Still, this does not address the main problem, namely, the inability to account for the role of incentives in the behavior of the individual entrepreneur. Clearly, the problem lies, in this particular issue, as in some others we shall consider below, in Kirzner's attempt to isolate the entrepreneurial function from the entrepreneurial person. It is not clear that this adds any value to his very valuable insights regarding the centrality of opportunities in entrepreneurship research.

Kirzner might, plausibly, attempt to salvage this distinction by conceding that incentives cannot logically influence the individual discovery of an opportunity, but it can, and will, influence the exploitation of said opportunity, and the latter is not an entrepreneurial function. The entrepreneurial function, he might argue, is confined to the discovery (the perception) of the opportunity and then ceases. The rest is "management."

This is also the essence of Kirzner's argument refusing to speculate about the antecedent conditions of successful entrepreneurship. To do so would be to delve into the realm of cognitive and management science - valid areas of research in which much has and is being done in this regard but areas of research beyond the scope of

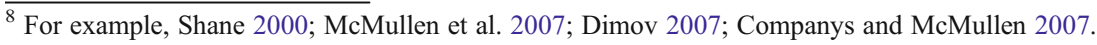


his interest as an economist. After all, he might say, investigating the determinants of differential intelligence is a valid line or research, but not for economists; so it is with the nature of differential alertness, a natural human trait, like intelligence.

To see why this will not do, let us reconsider the nature of opportunity as described in the previous section. Kirzner's attempt to sever the entrepreneurial function from the entrepreneurial person, and the role of alertness-discovery from the role of exploitation assumes that the opportunity can be perceived without considering any of the details of its exploitation. But, if, as I would argue, any entrepreneurial opportunity is constituted by its ingredients, as described above, it makes no sense to talk of opportunities as entities separate from the ingredients that constitute them. To perceive the opportunity one has to perceive it holistically as the potential to add value to resource-inputs. To see the opportunity one has to believe that this is possible, one has to believe that the circumstances within which the opportunity can be exploited, and the manner of its exploitation, will result in value-creation, and, hence, profit. One cannot think of an opportunity as a disembodied potential to add value, for example by referencing only the leftmost column in Table 1 . What is it exactly that the entrepreneur notices in Kirzner's system? How does this get communicated to the person who exploits it? In communicating his vision to the owner/manager does not the entrepreneur have to spell out why he thinks value can be created and, at least in broad outline, how this can be done (one thinks of a "business plan")? Or, alternatively, if it is the entrepreneur who is also the owner/manager of the project, does he not perceive the details at the time he notices the opportunity, at least in broad outline?

Many contributions have addressed the question of opportunity execution through successive stages as different aspects of entrepreneurship-for example discovery, preparation, execution, appropriation, etc. What I am asserting here is that at the initial spark of opportunity perception, the realization of an arbitrage opportunity, "the math will not work" without all three ingredient categories lining up favorably. Kirzner can be understood as focusing attention on the leftmost column of Table 1, on the simple difference in the ex-ante and ex-post values of the combined resources. But without the necessary complementary actions of resource-owners facilitated by shared understandings of what needs to be done the values will not work out and the arbitrage opportunity will not exist. Without the right cooperative resource inputs and without the ability to anticipate and plan for them (in an uncertain, dynamic world) as facilitated by a shared-framework of meanings and standards, there is no perceiving of the profit. It makes no sense to talk about perceiving or discovering an arbitrage opportunity without at the same time perceiving the whole package (at least in broad outline).

For these reasons, I would argue it is better to conceive of the entrepreneur (or the entrepreneurial team) as active participant in the project emerging out of the envisaged opportunity. In this sense, the entrepreneur is necessarily an owner, a stakeholder, in the project (Foss and Klein 2012, pp. 20, 66ff). If the opportunity is real, it is real because all of its synergistically constituted ingredients, including the values of the resources it uses and the manner of their combination and employment. Vision and execution are not so easily distinguished or separated. At the very least, since pure ideas cannot be owned, the entrepreneur must have control of assets, of resources, to appropriate any value (Manne 2013; Klein 2008). Opportunities, 
understood as encompassing all of the ingredients discussed, are amenable to "discovery" by alert entrepreneurs, in whose interest it may be, together with others, to exploit them. And such exploitation will surely depend on the right incentives. The right conditions/incentives produce opportunities for the execution of entrepreneurial projects. For this reason, we would argue that Kirzner's reluctance to venture outside the realm of narrow economics should be overcome. Economists have a lot to say about the insides of the business establishments in which value is added, and stimulated by Kirzner's lead should be, and have been, active participants in the growing field of entrepreneurship studies broadly understood.

\subsection{Discovered or created (found or made)}

But what exactly does it mean to talk of "discovering" opportunities. This has been a matter of some dispute in the literature. In particular the question has arisen as to whether entrepreneurial activities are "discovered" or "created" or both or either (Alvarez and Barney 2007, 2010; Buenstorf 2007; Casson and Wadeson 2007; Klein 2008; Venkataraman et al. 2012; Zhara 2008, to list just a few). One aspect of the issue appears to be whether the opportunity arises because of events exogenous to the entrepreneur (discovery) or whether it is a result of the entrepreneur's fertile imagination-seeing something that that was "not there before" (creation). Regardless of the triggering event, one can imagine this distinction relating to whether or not the entrepreneur simply noticed something that might have been obvious to anyone (like seeing the proverbial $\backslash \$ 100$ dollar bill lying on the sidewalk), or whether it required an act of creative imagination. For example, Venkataraman et al. speak evocatively of opportunities being "made or found" (2011, p. 26ff.). It is a matter of ontology and/or epistemology. Do opportunities "exist" before they are perceived? How does the entrepreneur come to know about them? What is the nature of this knowledge? And so on.

Considering an entrepreneurial opportunity as the perceived potential to create value, however, we can assert the following. Opportunities are prospective. Unless we can speak of future events as "existing" today, opportunities do not exist objectively in this sense. Retrospectively we may say something like: "that turned out to be a real opportunity" (pun on the word "real" intended). The knowledge that the entrepreneur possesses is a mixture of "hard" knowledge and expectations, which together subjectively and synergistically combine to make it a perceived opportunity. This is true of all entrepreneurial opportunities, however one characterizes them ontologically or epistemologically. Even the $\$ \$ 100$ bill on the sidewalk is only an opportunity in the sense that it suggests the prospect of gain if one can get to it before someone else picks it up and use it to acquire something of value - and it requires that others recognize it as valuable and be prepared to accept it - evaluation, actions and understandings (see also Venkataraman et al. 2011 p. 26). It is not the concept of "discovery" or "creation" that is in need of clarification, it is the concept of opportunity. Once this is done the problem of how it comes about is less paradoxical or mysterious.

It is easy to see that the value of any opportunity is unlikely to be a self-evident proposition, and that many perceptions of opportunity for profit are likely to fail or to be illusions. Successful exploitation of what turns out to be an entrepreneurial opportunity is likely to be a complex hybrid of astute judgment, skillful management 
and fortuitous unfolding of events. It is also evident that the likelihood both of the occurrence of such (perceived) opportunities, and their success, is dependent on the institutional framework, the historical context and the culture. A market system, with a stable, well-understood and reliable legal framework is more likely to have successful entrepreneurs than a system without these facilitating background conditions. This follows from the relationship between the three categories of ingredients that constitute an entrepreneurial opportunity.

\subsection{The entrepreneur and the firm}

A lot has been written recently on the relationship between the entrepreneur and the firm. Are some firms more entrepreneurial than others (Langlois 2007; Sautet 2001)? Do entrepreneurs need firms (Witt 1999)? This is connected to the role that values (input-output evaluations) play in constituting an opportunity. As explained, these evaluations do not occur in a vacuum. Mises spoke of the entrepreneur performing an "appraisement" (Mises 1998 [1949]); Frank Knight (1921) spoke of the entrepreneur as providing "judgment"; Some authors talk about the need for "leadership" (Foss 2001). All of these have in common the idea of evaluating resources and directing actions in a situation framed by certain (institutional) understandings but lacking the ability to assign categories and/or probabilities to well-identified possible future outcomes. There is real (Knightian) open-ended uncertainty. Crucially, the evaluation of resources and outputs is dependent upon certain necessary actions - these actions being reciprocally dependent upon expected resource and output values by way of signals and incentives. There is a necessary interdependence. If resource ownership/direction defines a firm, then the entrepreneur must have one. And the profitable firm, being constituted by an opportunity, is necessarily entrepreneurial.

\subsection{Entrepreneurship theory and practice}

Kirzner's entrepreneur is a theoretical construct. There is no one-to-one correspondence between the Kirznerian entrepreneur and any real-world person thought of as an entrepreneur. Yet Kirzner's theory has been responsible for widening the field of vision of entrepreneurship researchers beyond the view of entrepreneurs as practitioners of mundane practical skills - such as one finds in primers on entrepreneurship addressing basically how to run a business. Kirzner had alerted us to the importance of the entrepreneurial vision, the entrepreneur's ability to imagine how resources can be used in different ways to add value - to produce something new or to add efficiency.

Addressing the concept of opportunity and jettisoning Kirzner's strictures about alertness being costless and impervious to incentive, enables us to build a bridge from his theory to entrepreneurship practice. The entrepreneur is indeed someone who notices opportunities, but it is opportunities as described above that are relevant. To talk of an opportunity to add value to resources without addressing the necessary actions that have to be taken and the framework in which this can occur, is to empty the concept of opportunity almost to the point of incoherence. In noticing the opportunity, the entrepreneur necessarily, even if only unconsciously, must have in mind the ancillary conditions (ingredients) necessary for that to be thought of as an opportunity - else it is simply a fanciful idea. 
So, in studying entrepreneurship in the real-world one can certainly investigate the particular opportunity that particular people were associated with in an entrepreneurial venture. Thinking of an entrepreneurial opportunity as the potential to create value in this wider sense extends Kirzner's valuable insights into the practical field. By studying all three aspects of opportunity (evaluation, actions, understandings) we may gain greater insight into practical entrepreneurship (see Table 2).

\section{Market versus political entrepreneurship}

These considerations help as well in a consideration of economic policy. The framework within which an opportunity presents itself is the most important policy influence on entrepreneurship. Kirzner has written about the "perils of regulation" (Kirzner 1979) arguing that regulation is inimical to entrepreneurship, but his insistence that alertness is costless and impervious to incentives makes it difficult to sustain this claim. Expanding the view of opportunity, as present above, adds greatly to its plausibility. A policy environment heavily encumbered with regulatory requirements and impediments, would, for that reason, be one in which fewer opportunities would arise. Such regulatory obstacles make the necessary actions more costly to take, and render the evaluation of inputs and outputs less favorable, reliable and meaningful. Direct taxation is just the most obvious and basic type of regulation.

At the same time however, understanding opportunity in the way we suggest, leads us to expect a different kind of entrepreneurship to be encouraged by highly regulated or centrally planned economies. Entrepreneurship in highly regulatorily constrained environments predictably takes the form of exploiting opportunities to create value in the form of personal and political alliances for the establishment of special privileges and considerations (Baumol 1996). One thinks of two highly successful real-world entrepreneurs in Carlos Slim and Bill Gates (ranked frequently as the two richest men in the world). The former's entrepreneurial success comes from successfully exploiting opportunities to secure highly valuable state-sanctioned monopolies (thereby raising the value to him of the resources employed). The latter's success, by contrast, comes from the exploitation of highly valuable opportunities to create value for untold millions by way of providing new consumer and producer goods.

This contrast suggests a role for the "political entrepreneur," the individual who sees value in transforming the policy environment into one more favorable to the exploitation of market opportunities form one that functions by the securing of special privileges (Leeson and Boettke 2009). The presence or absence of such

Table 2 Building a Bridge from Theory to Practice

Mundane entrepreneurship

Pure entrepreneurship — disembodied arbitrage

Skills necessary to run a business

Entrepreneur as someone who creates value by evaluating resources, directing actions, in a facilitating framework of shared understandings. 
opportunities for political entrepreneurship is more difficult to predict, being a matter of the political development of each individual economy.

\section{Conclusion}

A reformulation and unpacking of the concept of entrepreneurial opportunity to include it's three categories of essential ingredients, provides a fruitful framework for applying Israel Kirzner's approach to entrepreneurship. It provides a way of bridging the entrepreneur as someone alert to opportunities to create value, to real world situations requiring the entrepreneur's evaluation of resource-inputs and the prospective final outputs, and his perception of what actions are necessary and need to be coordinated, in an environment of understandings that are sufficiently shared and the entrepreneur's judgments are sufficiently accurate for this to happen. Understood in this way, it is no surprise that entrepreneurial "discovery" is not more commonplace. The market process is required to sift the many rival perceptions of would-be opportunities to create value in order to find the few that are real.

To successfully understand entrepreneurial opportunities one must then understand not only how the entrepreneur is able to provide superior evaluations, one must address also the coordination of resources, and the strategy of dealing with rival producers as well as the important aspects of the institutional framework of shared understandings in which action takes place. Only by gaining a better understanding of all of these interrelated dimensions of opportunity, can entrepreneurship be fully understood.

\section{References}

Alvarez, S. A., \& Barney, J. B. (2007). Discovery and creation: alternative theories of entrepreneurial action. Strategic Entrepreneurship Journal, 1, 11-26.

Alvarez, S. A., \& Barney, J. B. (2010). Entrepreneurship and epistemology: the philosophical underpinnings of the study of entrepreneurial opportunities. The Academy of Management Annals, $4(1), 557-583$.

Baumol, W. J. (1996). Entrepreneurship: productive, unproductive, and destructive. Journal of Business Venturing, 11(1), 3-22.

Buenstorf, G. (2007). Creation and pursuit of entrepreneurial opportunities: an evolutionary economics perspective. Small Business Economics, 28, 323-337.

Casson, M. \& Wadeson, N. (2007). The Discovery of Opportunities: Extending the Economic Theory of the Entrepreneur. Small Business Economics, 28, 285-300.

Companys, Y. E., \& McMullen, J. S. (2007). Strategic entrepreneurs at work: the nature, discovery, and exploitation of entrepreneurial opportunities. Small Business Economics, 28, 301-322.

Davidsson, P. (2004). Researching entrepreneurship. New York: Springer.

Dimov, D. (2007). From opportunity insight to opportunity intention: the importance of person-situation learning match. Entrepreneurial Theory and Practice, 31, 561-583.

Eckhardt, J. T., \& Shane, S. (2003). Opportunities and entrepreneurship. Journal of Management, 29(3), $333-349$.

Foss, N. (2001). Leadership, beliefs and coordination: an explorative discussion. Industrial and Corporate Change, 10(2), 357-388.

Foss, N. J., \& Klein, P. G. (2008). Entrepreneurship: from opportunity discovery to judgement. Working paper.

Foss, N. J., \& Klein, P. G. (2010). Entrepreneurial alertness and opportunity discovery: Origins, attributes, critique. In H. Landström \& F. Lohrke (Eds.), The historical foundations of entrepreneurship research (p. Chapter 5). Northampton: Edward Elgar. 
Foss, N. J., \& Klein, P. G. (2012). Organizing entrepreneurial judgement: A new approach to the firm. Cambridge: Cambridge University Press.

Kirzner, I. (1973). Competition and entrepreneurship. Chicago: University of Chicago Press.

Kirzner, I. M. (1979). Perception, opportunity and profits: Studies in the theory of entrepreneurship. Chicago and London: University of Chicago Press.

Kirzner, I. M. (1980). The primacy of entrepreneurial discovery. The Prime Mover of Progress: The Entrepreneur in Capitalism, and Socialism - Papers on the Role of the Entrepreneur. London: Institute of Economic Affairs, pp. 3-28.

Kirzner, I. M. (1985). Discovery and the capitalist process. Chicago and London: University of Chicago Press.

Kirzner, I. M. (2009). The alert and creative entrepreneur. Small Business Economics, 32(2), 145-152.

Klein, P. G. (2008). Opportunity discovery, entrepreneurial action, and economic organization. Strategic Entrepreneurial Journal, 2, 175-190.

Knight, F. (1921). Risk, uncertainty and profit. Boston: Hart, Schaffner \& Marx; Houghton Mifflin Co. available at: http://www.econlib.org/library/Knight/knRUP.html.

Langlois, R. N. (2007). The entrepreneurial theory of the firm and the theory of the entrepreneurial firm. Journal of Management Studies, 44, 1107-1124. doi:10.1111/j.1467-6486.2007.00728.x.

Leeson, P. T., \& Boettke, P. J. (2009). Two-tiered entrepreneurship and economic development. International Review of Law and Economics, 29(3), 252-259. Available at SSRN: http://ssrn.com/ abstract $=903475$.

Lewin, P. (1998). The firm, money and economic calculation: considering the institutional Nexus of market production. American Journal of Economics and Sociology, 57(4), 499-512.

Lewin, P. (2002). Enterpreneurship and the defense of capitalism: an examination of the work of Israel Kirzner. Journal des Economistes et des Etudes Humaines, 12(2). doi:10.2202/1145-6396.1057. Available at: http://www.bepress.com/jeeh/vol12/iss2/art2.

Lewin, P., \& Phelan, S. E. (2001). Rent and resources: A market process perspective. In N. Foss \& P. Klein (Eds.), Entrepreneurship and the firm: Austrian perspectives on economic organization. Aldershot: Edward Elgar.

Manne, H. C. (2013). Resurrecting the ghostly entrepreneur. Retrieved May 2, 2013, from http:// www.masonlec.org/site/rte uploads/files/Manne\%20-\%20Kirzner paper 2-25-13.pdf.

McCaffrey, M. (2013). On the theory of entrepreneurial incentives and alertness. Entrepreneurship: Theory and Practice. doi:10.1111/etap.12013.

McMullen, J. S., Plummer, L. A., \& Acs, Z. J. (2007). What is an entrepreneurial opportunity. Small Business Economics, 28, 273-283.

Mises, L. v. (1980 [1951]). Profit and loss. In L. v. Mises (Ed.), In planning for freedom. Spring Mills.

Mises, L. v. (1998 [1949]). Human action. Auburn: Ludwig von Mises Institute.

Richardson, G. B. (1960). Information and investment: A study in the working of competitive economy. Oxford: Clarendon.

Sautet, F. (2001). An entrepreneurial theory of the firm. London: Routledge.

Schumpeter, J. (1911 [1982]). The theory of economic development. Piscataway, NJ: Transaction Publishers.

Schumpeter, J. (1942 [2010]). Capitalism, socialism and democracy. London: George Allen and Unwin.

Shane, S. (2000). Prior knowledge and the discovery of entrepreneurial opportunities. Organization Science, 11(4), 448-469.

Shane, S. (2004). A general theory of entrepreneurship: The individual-opportunity Nexus. Northampton: Edward Elgar.

Shane, S., \& Venkataramon, S. (2000). The promise of entrepreneurship as a field of research. Academy of Management Review, 1(1), 217-226.

Short, J. C., Ketchen, D. J., Shook, C. I., \& Ireland, D. R. (2009). The concept of "opportunity" in entrepreship research: past accomplishments and future challenges. Journal of Management, 36, 40-65.

Venkataraman, S., Sarasvathy, D. S., Dew, N., \& Foster, W. R. (2012). Reflections on the 2010 AMR decade award: whither the promise? Moving forward with entrepreneurship as a science of the artificial. Academy of Management Review, 37(1), 21-33. doi:10.5465/amr.2011.0079.

Witt, U. (1999). Do entrepreneurs need firms? A contribution to a missing chapter in Austrian economics. The Review of Austrian Economics, 11, 99-109.

Zhara, S. A. (2008). The virtuous cycle of discovery and creastion of entrepreneurial opportunities. Strategic Entrepreneurship Journal, 2, 243-257. 